\title{
Numerical prediction of mechanical properties of zirconium alloy with hydrides using finite element method
}

\author{
Remigijus Janulionis, \\ Gintautas Dundulis, \\ Rita Kriūkienè, \\ Albertas Grybėnas \\ Lithuanian Energy Institute, \\ Breslaujos St. 3, \\ 44403 Kaunas, Lithuania \\ Email:Remigijus.Janulionis@lei.lt
}

During nuclear power plant (NPP) operation, degradation effects like ageing, corrosion, fatigue, and others may significantly impact component integrity. One of the degradation mechanisms is hydrogen absorption. High levels of hydrogen in zirconium alloys can lead to the formation of zirconium hydrides and that can influence material properties. Therefore, determination of material properties under different levels of hydrogen concentration in zirconium alloys is important. It is not always possible to conduct an experimental testing. Therefore, there is a need for alternative methods for determination of material properties. This article presents the numerical prediction of material properties of zirconium $2.5 \%$ niobium alloy with hydrides.

According to the objective of the work, numerical prediction was performed using the finite element (FE) method. This was done by creating a finite element model of zirconium hydride embedded in zirconium alloy. The geometry and size of hydride were measured from a real specimen. The size of zirconium alloy surrounding the hydride was selected in such a way that hydride volume part in the model would match experimental measurements. The prognosis results were compared with the experimental data.

Keywords: finite element method, hydride, hydrogen, zirconium alloy, mechanical properties

\section{INTRODUCTION}

Zirconium alloys are used for manufacturing of fuel channels and fuel cladding used in NPPs. Under long operation, components made of zirconium alloys are affected by pressure, radiation, corrosion, etc. Radiation, hydrogen absorption caused by corrosion process and other degradation mechanisms can change mechani- cal properties of alloy, i.e. make it more brittle. Hydrogen absorption is one of the factors for determination of the lifetime of fuel channels (FC) made of zirconium $2.5 \%$ niobium alloy. Hydrogen in zirconium alloys leads to the formation of zirconium hydrides. As hydrides are brittle, their formation in zirconium alloy do degrade its mechanical properties. The presence of hydrides reduces ductility and resistance to brittle 
fracture [1-4]. Therefore, knowing of mechanical properties under different levels of hydrogen concentration in zirconium alloy is important. Usually, mechanical properties of materials are determined by conducting experiments. However, the experimental testing of material which was in operation is complicated. Therefore, it is useful to create a possibility of creating alternative methods for the prediction of mechanical properties.

Mechanical properties of the material are one of the key elements describing its behaviour under loading. It is an input parameter in structural integrity analysis. The change of material properties has a direct link to the structure's or component's capability to withstand its acting loads. An increase in yield strength will result in a more brittle pipe failure [5]. It is very important as delay hydride cracking is one of the biggest issues for fuel channels and fuel claddings $[6,7]$.

No research papers directly presenting the numerical prediction of mechanical properties of zirconium alloy with hydrides were found. Some research papers have been found on numerical modelling of hydrogen and hydrides distribution in zirconium alloy [8], numerical modelling of hydrides growth [9] and hydrides shape and orientation [10] in zirconium alloy in the presence of hydrogen using the finite element method. More papers can be found on fracture modelling of zirconium alloy with hydrides [1113], etc. In fracture modelling papers, authors do create finite eleement models where one or few zirconium hydrides are embedded in zirconium matrix, and this is similar to what we used in the numerical prediction of mechanical properties of zirconium alloy with hydrides.

The aim of this work is to numerically predict the mechanical properties of zirconium alloy with hydrides for different hydrogen concentrations. The number of hydrides and their size in the metal are the key aspects what makes changes of mechanical properties. Therefore, the length, width and volume part of hydride in zirconium alloy was measured. According to measurement results, the finite element model of zirconium alloy with hydride was created. Predicted mechanical properties were compared with experimental data.

The current work is the continuation of earlier work [14]. The previous work showed the nu- merical prediction of mechanical properties of zirconium alloy with hydrogen concentration at $100 \mathrm{ppm}$. For this purpose the finite element model was created by using plain strain and plain stress $2 \mathrm{D}$ elements. In this analysis, axial-radial direction of hydrides was evaluated. However, extended research has revealed that hydrides in the fuel channel have the dominant orientation, which is in axial-tangential direction. Therefore, the current research does evaluate zirconium alloy properties where hydride is in this orientation. The new finite element model was meshed with shell elements and prognosis was made for zirconium alloy with three different hydrogen concentrations.

\section{NUMERICAL PREDICTION OF MECHANICAL PROPERTIES}

During exploitation of a NPP, various components situated in reactor core are affected by radiation. Fuel channels and claddings are among these components. Therefore, experimental investigation of the influence of hydrides on mechanical properties of zirconium alloy ( $\mathrm{Zr}-2.5 \mathrm{Nb})$, which is used for manufacturing of fuel channels, is complicated. That is why alternative methods are important. In this work the finite element method was used for the prediction of mechanical properties. The idea of numerical modelling is to try to simulate the tension experiment of zirconium alloy containing hydrides. The models consist of two materials: zirconium alloy and hydride. Various FE model designs have been tested. However, the best results so far have been achieved by the FE model were one hydride surrounded by zirconium alloy matrix was created.

\section{Mechanical properties of $\mathrm{Zr}$ alloy and hydride} The mechanical properties of $\mathrm{Zr}-2.5 \mathrm{Nb}$ are presented in Table 1. Here $E$ is the modulus of elasticity, $R_{\mathrm{p} 0.2}$ is yield strength, $R_{\mathrm{m}}$ is ultimate strength, $A$ is rupture strain, and $Z$ is cross-section area reduction.

Table 1. Mechanical properties of Zr-2.5Nb alloy at room temperature [15]

\begin{tabular}{c|c|c|c|c}
\hline $\boldsymbol{E}, \mathrm{GPa}$ & $\boldsymbol{R}_{\mathrm{p} 0.2, \mathbf{M P a}}$ & $\boldsymbol{R}_{\mathrm{m},} \mathbf{M P a}$ & $\boldsymbol{A}, \%$ & $\mathbf{Z}, \%$ \\
\hline 34.4 & 411 & 492 & 14.78 & 62.2 \\
\hline
\end{tabular}


The mechanical properties of hydride were modelled according to methodology [16]. According to this methodology, the modulus of elasticity $E$ and the tensile strength of typical hydride can be calculated analytically. The calculation of these properties was done as in previous research, i.e. first of all the modulus of elasticity was calculated from dependency on temperature and tensile strength from dependency on $E$ using analytical approach [14].

After determination of mechanical properties of hydride, the stress-strain curve can be reconstructed. The true stress-strain curve of zirconium alloy and hydride used in numerical simulation is presented in Fig. 1.

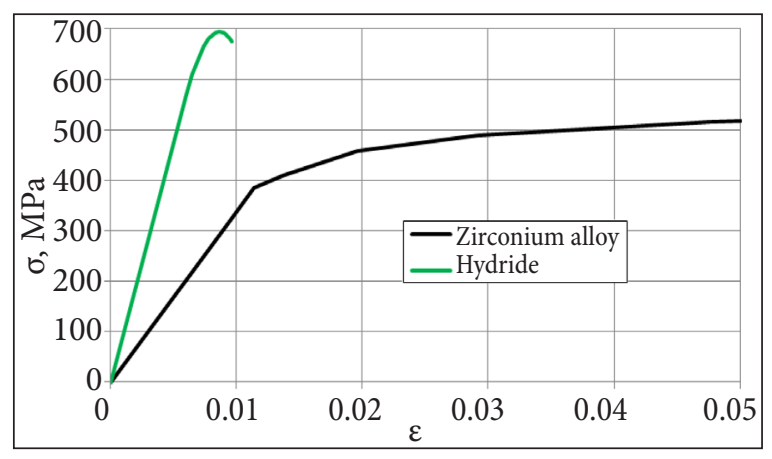

Fig. 1. True stress-strain curve of zirconium alloy and hydride [14]

\section{Geometry of hydride}

The idea of simulation of mechanical properties of zirconium alloy with hydrides is to create a small portion of zirconium alloy model embedded with a single hydride. In order to create such a model, investigation of the geometry of hydride is important. It was noticed that zirconium alloy samples with different concentrations of hydrogen contain not only a higher number of hydrides, but also different length and width. The orientation of hydrides is also important. Figure 2 shows hydrides distribution in the $\mathrm{Zr}$ $2.5 \mathrm{Nb}$ alloy pipe at hydrogen concentration of $140 \mathrm{ppm}$. According to the figure, the hydrides have a tendency to form in axial-tangential direction. The same hydride orientation is also observed in pressurized heavy water reactors [4]. This hydride orientation is related to the manufacturing technology of the pipe. As the manufacturing process has hot and cold rolling processes [17] it makes zirconium grains to form in elongated shape oriented in axial-tangential direction. This is the main reason what makes hydrides to have this shape. During the operation of the pipe, the major loading force is internal pressure. Due to pressure the highest stress component in the pipe is hoop stress, the stress component which has circumferential direction around the pipe. According to this, the experiments we compare our results with [15] were carried out in tangential direction. Therefore, numerical simulations were also carried out in tangential direction.

For the measurement of hydrides samples were cut from the $\mathrm{Zr}-2.5 \mathrm{Nb}$ alloy fuel channel and specially prepared. Electrolytic hydriding [18] in elevated temperature was used to add hydrogen into the samples. Cooling was done in a furnace at the rate of $0.5^{\circ} \mathrm{C} / \mathrm{min}$, what is close to the fuel channel cooling rate at reactor shut-down. The measurement of hydrides length was made at three different concentrations: 45 ,

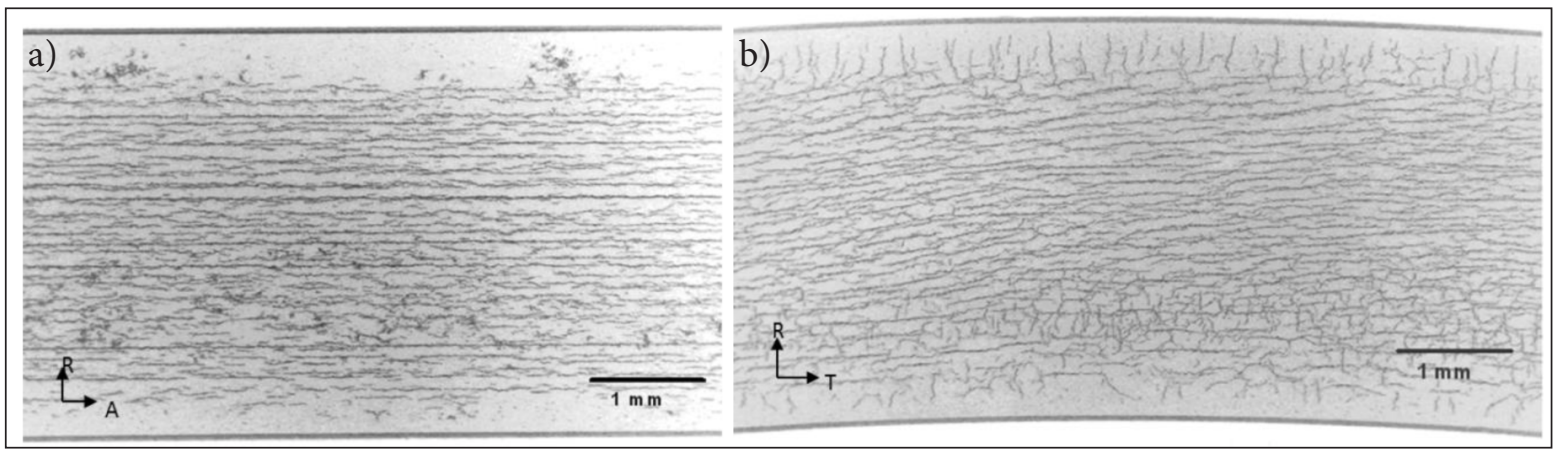

Fig. 2. Hydrides distribution in zirconium alloy of the fuel channel at hydrogen concentration of $140 \mathrm{ppm}$ : a) radial-axial cross-section; b) radial-tangential cross-section 
100 and $250 \mathrm{ppm}$. The arithmetic average of hydride length at different hydrogen concentration is presented in Fig. 3 as diamond shaped blue colour dots. Similarly the average hydride width was measured, only different hydrogen concentrations were chosen, i.e. 22, 45, 95 and 137 ppm. The width measurement results are presented in Fig. 3 as square shape red colour dots. The size measurement results show that while increasing hydrogen concentration both hydride length and width also increase.

The length and thickness of hydride do not tell how much zirconium alloy is surrounding it. Therefore, the volume part that hydrides take in zirconium alloy should be measured. To estimate the volume fraction of hydrides in zirconium alloy the statistical stereological method of area [19] was used. According to this method, the area of the hydride fraction is equal to its volume fracture. The measurements were made in two directions: in axial-radial (A-R) and in radial-tangential ( $\mathrm{R}-\mathrm{T})$. Measurement results are presented in Fig. 4.

Having the data of length, width and volume part of hydrides it is possible to create a FE model of zirconium alloy with hydride.

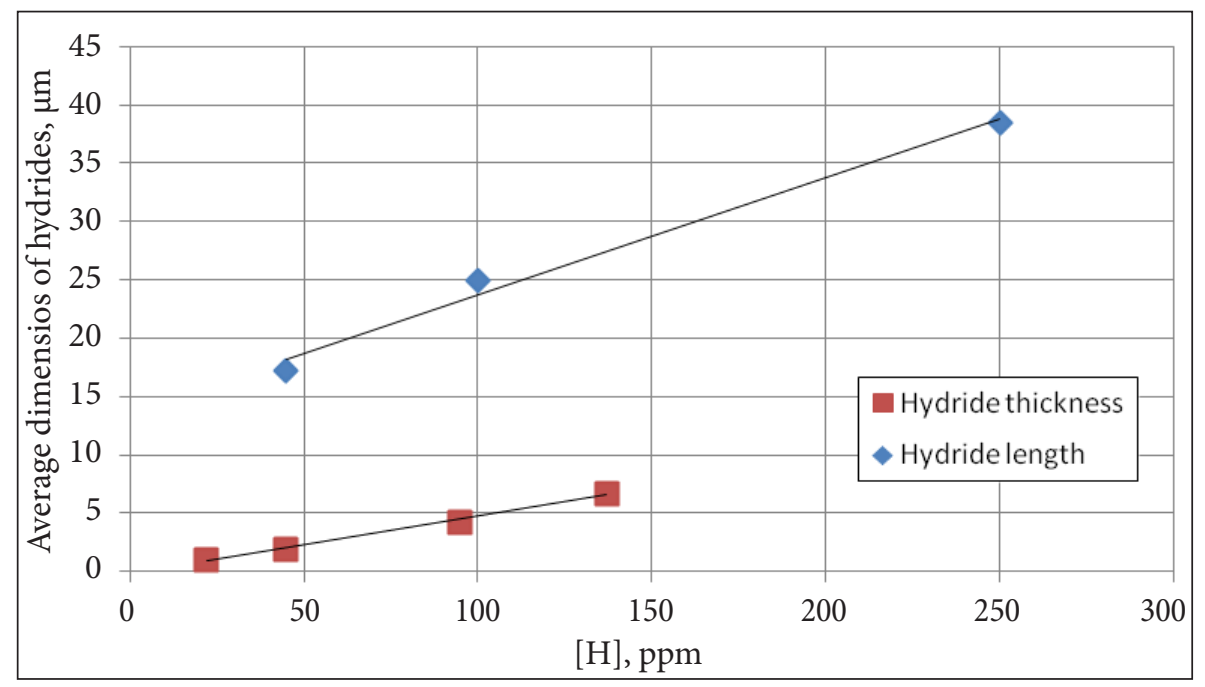

Fig. 3. Average hydride size vs. hydrogen concentration

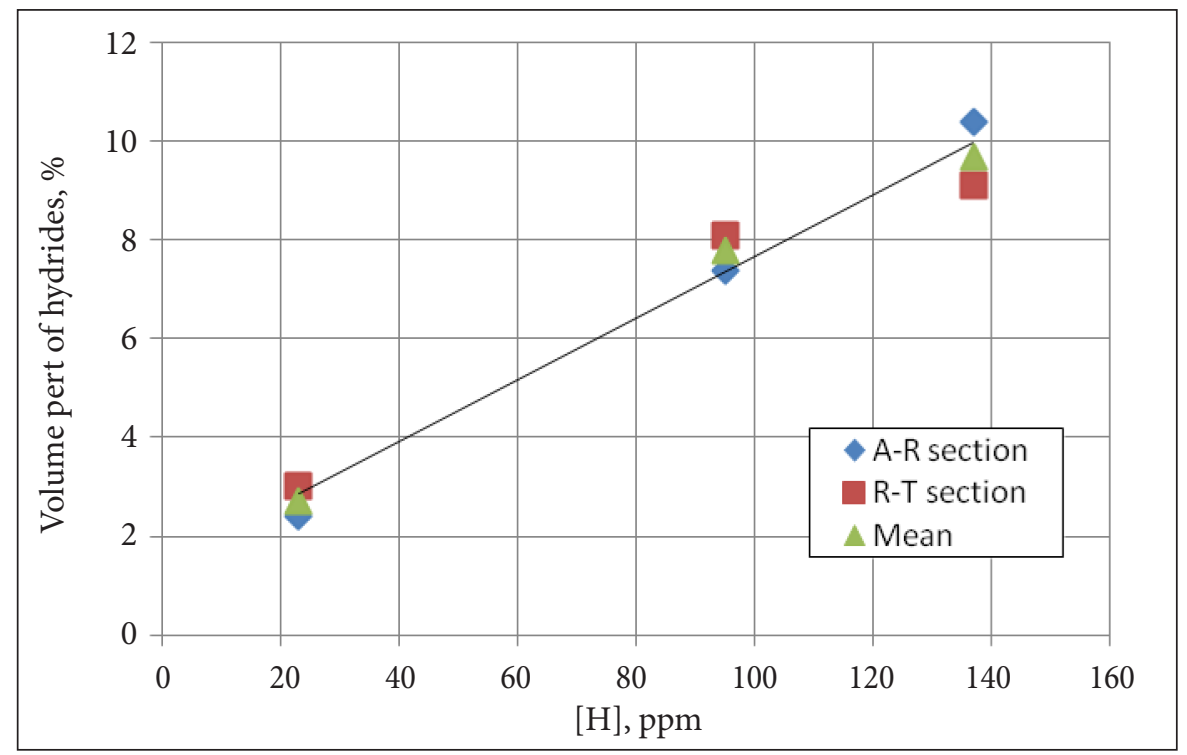

Fig. 4. Volume part of hydrides vs. hydrogen concentration 


\section{Finite element model}

Previously it was explained that hydrides in the $\mathrm{Zr}-2.5 \mathrm{Nb}$ fuel channel tend to form in axial tangential directions, the major stresses during the operation of FC are hoop stresses, and experimental tests [15] were conducted also in tangential direction. The idea of numerical modelling is to try to simulate experiment testing on a micro-scale; i.e. the created FE model would be one real size hydride surrounded by zirconium alloy instead of a real size specimen with a cluster of hydrides. The micro-model should show how one hydride, without interacting with other hydrides, influences the change of mechanical properties. Therefore, hydride and loading orientations in the prepared model should match the orientations in experimental testing. The FE models of the zirconium alloy with hydride in case of hydrogen concentration of 52, 100 and 140 ppm are presented in Fig. 5a. The sizes of hydrides in the models were taken from the measurements described previously, where the length varied from 18.8 up to $27.7 \mu \mathrm{m}$. The zirconium alloy was modelled as a square and the size of the edge was selected in such a way that the volume part of hydride matched the measurements presented in Fig. 4. The thick- ness of the model was equal to $1 \mu \mathrm{m}$. To avoid any stress concentrators the ends of hydrides were made rounded. Finite element models were prepared using ABAQUS 6.11 [20]. The model was meshed with S8R shell elements. These are 8 -node shell elements with 6 degrees of freedom per node and 5 integration points per thickness [20]. The size of FE mesh was around $0.5 \mu \mathrm{m}$ in all cases. The FE mesh in case of hydrogen concentration of $140 \mathrm{ppm}$ is presented in Fig. 5b. As the model of one hydride surrounded by zirconium alloy has two symmetry planes, only $1 / 4$ of hydride and zirconium alloy was modelled. Therefore, symmetry boundary conditions were applied to horizontal bottom and vertical right edges of the model (see Fig. 5a). The displacement of top horizontal edge was applied as load. To be able to calculate stresses for reconstruction of the stress-strain curve as the calculation result, the reaction force was measured.

\section{Results and discussion}

The modelling of stress-strain curves of zirconium alloy with hydrogen concentration of 52, 100 and $140 \mathrm{ppm}$ was performed. The analysis results are presented in Fig. 6 in case of hydrogen concentration of $140 \mathrm{ppm}$. In the figure, the numerically

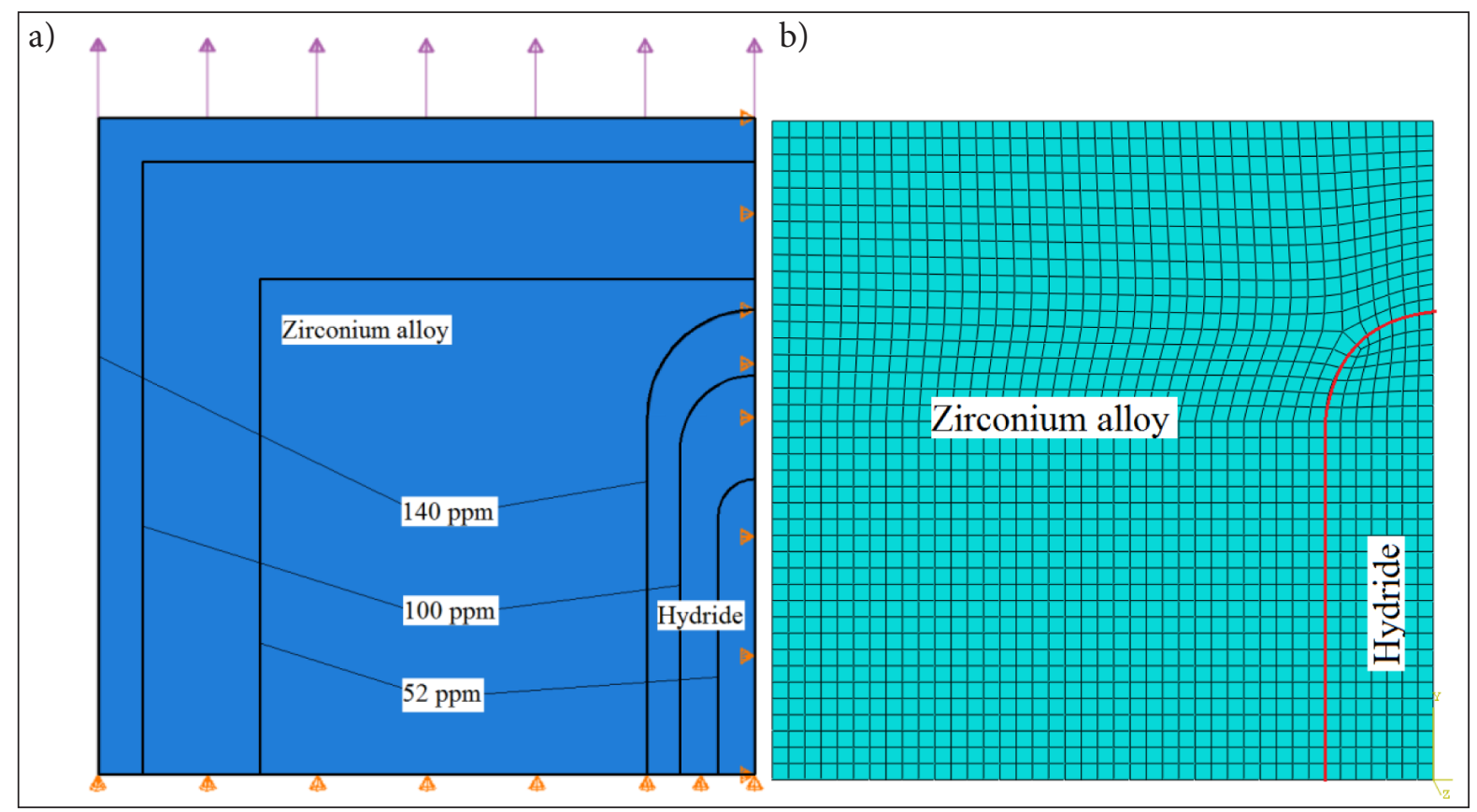

Fig. 5. FE model and mesh of zirconium alloy with hydride: a) geometry, loading and boundary conditions in case of hydrogen concentration of 52, 100 and $140 \mathrm{ppm}$; b) finite element mesh in case of hydrogen concentration of $140 \mathrm{ppm}$ 


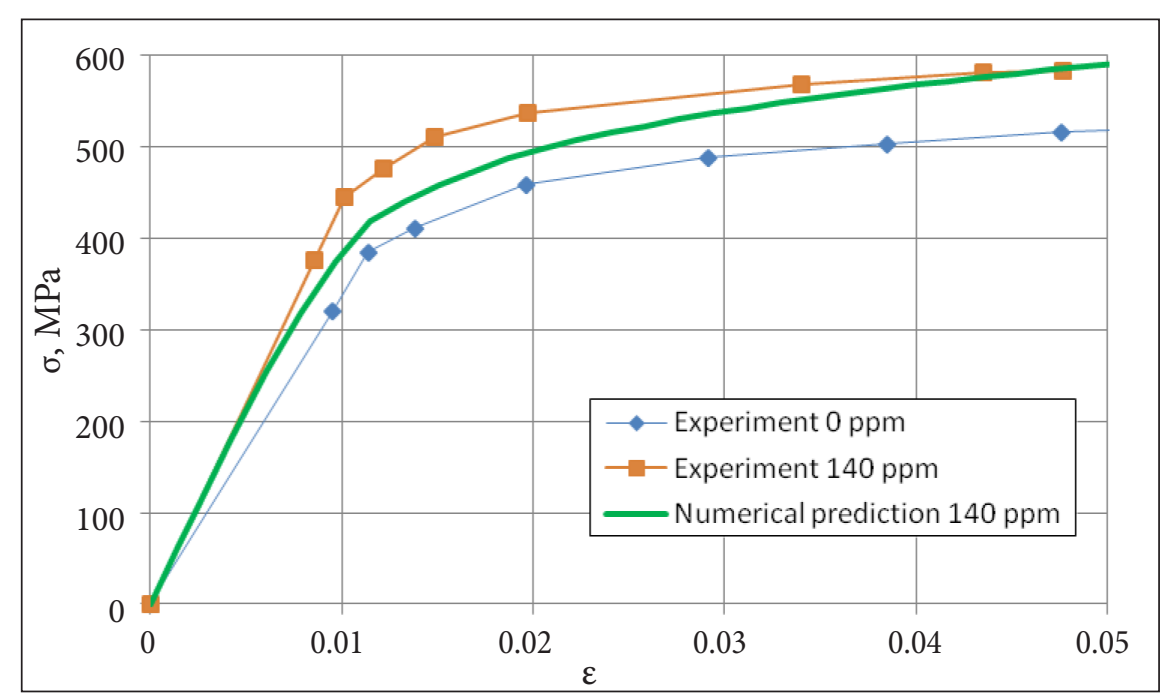

Fig. 6. Numerically predicted stress-strain curve of zirconium alloy with hydrogen concentration of $140 \mathrm{ppm}$ in comparison with experimental data

predicted stress-strain curve is compared with experimental data. It can be seen that coincidence of the elastic part of the numerically predicted curve with experimentally measured is acceptable. However, the values start to deviate in the plastic region. Another thing should be mentioned, i.e. the numerically reconstructed stress-strain curve does not show a drop of stress. Therefore, it is not possible to predict ultimate strength. In experimental testing the drop of stress does occur due to the necking of the specimen. In numerical simulation necking can be forced by artificial weakening of a small part of the model. This can be done by reducing the cross-section of the specimen in the desired location by a small amount, or by decreasing tensile strength of a few finite elements. This is planned to be done in future works.

A comparison of the numerically predicted and experimentally determined modulus of elasticity at different hydrogen concentration is shown in Fig. 7. Figure also shows the linear regression line of experimental data. Numerical simulation shows that the modulus of elasticity is increasing at higher hydrogen concentration values what was confirmed by experimental tests [15].

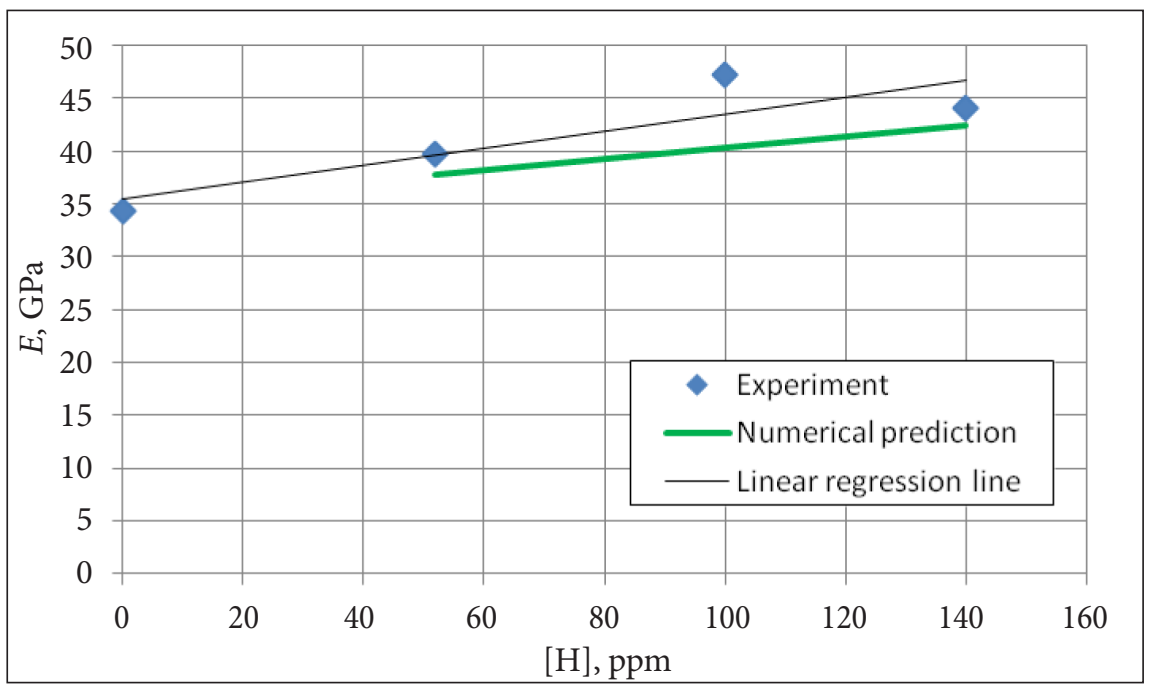

Fig. 7. Modulus of elasticity of zirconium alloy vs. hydrogen concentration 
Table 2. Numerical simulation and experimental results [15] of mechanical properties of $\mathrm{Zr}$-2.5Nb alloy with hydrides

\begin{tabular}{|c|c|c|c|c|c|c|}
\hline \multirow{2}{*}{$\begin{array}{c}\text { Hydrogen } \\
\text { concentration, ppm }\end{array}$} & \multicolumn{2}{|c|}{$E, \mathrm{GPa}$} & \multirow{2}{*}{ Deviation, \% } & \multicolumn{2}{|c|}{$R_{\mathrm{p} 0.2}, \mathrm{MPa}$} & \multirow{2}{*}{$\begin{array}{c}\text { Deviation, } \\
\%\end{array}$} \\
\hline & $\begin{array}{l}\text { Experimental } \\
\text { linear regression }\end{array}$ & $\begin{array}{l}\text { Numerical } \\
\text { prediction }\end{array}$ & & Experiment & $\begin{array}{l}\text { Numerical } \\
\text { prediction }\end{array}$ & \\
\hline 52 & 39.7 & 37.8 & 4.8 & 368 & 418 & 13.6 \\
\hline 100 & 43.5 & 40.4 & 7.1 & 470 & 420 & 10.6 \\
\hline 140 & 46.7 & 42.5 & 9.0 & 470 & 420 & 10.6 \\
\hline
\end{tabular}

This effect can be explained as the volume part of hydride is bigger (see Fig. 4) at a higher hydrogen concentration value, it means hydride has more influence on zirconium alloy. As the modulus of elasticity of hydride (see Fig. 1) is higher than zirconium alloy, such combination results in the rise of total modulus of elasticity.

Table 2 presents a comparison of the numerically predicted and experimentally determined modulus of elasticity and yield strength. In this table, experimentally determined $E$ values were recalculated from the linear regression line. The comparison shows that predicted $E$ values deviate up to $9 \%$. Depending on hydrogen concentration the predictions of yield strength do deviate from the experiment by $11-14 \%$. Numerical prediction shows an increase of yield strength values at a higher hydrogen concentration what does agree with experimental results.

\section{SUMMARY AND CONCLUSIONS}

The numerical prediction of mechanical properties of zirconium alloy with different levels of hydrogen concentrations was performed. For this purpose the finite element method was used. The created model consists of two materials: zirconium alloy and one hydride. The length, width and volume part of hydrides were experimentally measured and arithmetically averaged. The FE model was created according to measurements. Depending on hydrogen concentration a different size of hydride and zirconium alloy portion surrounding it was used. Mechanical properties of zirconium alloy tested experimentally and hydride properties calculated analytically were used in the analysis.

A comparison of numerically predicted and experimentally determined mechanical properties of zirconium alloy with hydrides at dif- ferent hydrogen concentrations has been done. It showed that the used FE model does predict elastic behaviour of the material well. Predicted $E$ values deviate up to $9 \%$. The predictions of yield strength do deviate from the experiment by $11-14 \%$. This shows that plastic behaviour of material is not predicted as expected. Also, using the current model it is not possible to determine ultimate strength. Therefore, further development of the model has to be done. Next step would be to develop a 3D model. This is planned to be done in the closest future.

Received 1 February 2018 Accepted 20 February 2018

References

1. Coleman C. E., Hardie D. The hydrogen embrittlement of a-zirconium - A review. Journal of the Less-Common Metals. 1966. Vol. 11. P. 168.

2. Kuroda M., Yamanaka S., Setoyama D., Uno M., Takeda K., Anada H., Nagase F., Uetsuka H. Tensile test of hydrided Zircaloy. Journal of Alloys and Compounds. 2002. Vol. 330. P. 404-407.

3. Bertolino G., Meyer G., Perrez I. J. Mechanical properties at room temperature in ZRY-4 by hydro-gen brittleness. Materials Research. 2002. Vol. 5. No. 2. P. 125-129.

4. Bind A. K., Sunil S., Singh R. N. Effect of hydrogen isotope content on tensile flow behavior of $\mathrm{Zr}-2.5 \mathrm{Nb}$ pressure tube material between 25 and $300^{\circ} \mathrm{C}$. Journal of Nuclear Materials. 2016. Vol. 476. P. 5-12.

5. Chun-Qing L., Guoyang F., Wei Y., Shangtong Y. Derivation of elastic fracture toughness for ductile metal pipes with circumferential external cracks under combined tension and bending. Engineering Fracture Mechanics. 2017. Vol. 178. P. 39-49. 
6. Sunil S., Bind A. K., Khandelwal H. K., Singh R. N., Chakravartty J. K. Delayed hydride cracking behavior of $\mathrm{Zr}-2.5 \mathrm{Nb}$ alloy pressure tubes for PHWR700. Journal of Nuclear Materials. 2015. Vol. 466. P. 208-219.

7. Jong-Dae H., Hyo-Chan K., Ju-Seong K., YongSik Y., Dong-Hak K. Delayed hydride cracking assessment of PWR spent fuel during dry storage. Nuclear Engineering and Design. 2017. Vol. 322. P. 324-330.

8. Mankosa M., Avramova M. Three-dimensional multi-physics modeling of hydrogen and hydride distribution in zirconium alloy cladding. Progress in Nuclear Energy. 2018. Vol. 105. P. 294-300.

9. Bair J., Zaeem M. A., Tonks M. A review on hydride precipitation in zirconium alloys. Journal of Nuclear Materials. 2015. Vol. 466. P. 12-20.

10. Sharma R. K., Tewari A., Singh R. N., Kashyap B. P. Optimum shape and orientation of $\delta$-hydride precipitate in a-zirconium matrix for different temperatures. Journal of Alloys and Compounds. 2018. Vol. 742. P. 804-813.

11. Suman S., Kaleem Khan M., Pathak M., Singh R. N. 3D simulation of hydride-assisted crack propagation in zircaloy-4 using XFEM. International Journal of Hydrogen Energy. 2017. Vol. 42. P. 18668-18673.

12. Allen G. B., Kerr M., Daymond M. R. Measurement and modeling of strain fields in zirconium hydrides precipitated at a stress concentration. Journal of Nuclear Materials. 2012. Vol. 430. Iss. 1-3. P. 27-36.
13. Kubo T., Kobayashi Y., Uchikoshi H. Determination of fracture strength of $\delta$-zirconium hydrides embedded in zirconium matrix at high temperatures. Journal of Nuclear Materials. 2013. Vol. 435. P. 222-230.

14. Dundulis G., Karalevičius R., Janulionis R., Grybènas A. Modelling of the $\mathrm{Zr}-2.5 \mathrm{Nb}$ alloy properties with hydrides. Mechanika. 2007. Vol. 2. P. 23-26.

15. Daunys M., Dundulis R., Grybenas A., Krasauskas P. Hydrogen influence on mechanical and fracture mechanics characteristics of zirconium $\mathrm{Zr}-2.5 \mathrm{Nb}$ alloy at ambient and elevated temperatures. Nuclear Engineering and Design. 2008. Vol. 238. Iss. 10. P. 2536-2545.

16. Varias A. G., Massih A. R. Temperature and constrain effects on hydride fracture in zirconium alloy. Engineering Fracture Mechanics. 2000. Vol. 65. P. 29-54.

17. Zamovski A. S., Nikulina A. V., Reshetnikov N. G. Zirconium Alloys in Nuclear Power Engineering. Moscow: Energoatomizdat, 1994. 256 p. ISBN 5-283-03767-3 (in Russian).

18. Makarevičius V., Grybenas A., Levinskas R. Controlled hydriding of $\mathrm{Zr}-2.5 \% \mathrm{Nb}$ alloy by thermal diffusion. Materials Science. 2001. Vol. 7. Iss. 4. P. 249-251.

19. Ohser J., Mucklich F. Statistical Analysis of Microstructures in Material Science. John Wiley \& Sons, Ltd, 2000. 381 p. ISBN 978-0-471-97486-4.

20. ABAQUS/Standard User's Manual, Version 6.11. 
Remigijus Janulionis, Gintautas Dundulis, Rita Kriūkienė, Albertas Grybènas

CIRKONIO LYDINIO SU HIDRIDAIS

MECHANINIŲ SAVYBIŲ SKAITINIS PROGNOZAVIMAS NAUDOJANT BAIGTINIŲ ELEMENTŲ METODĄ

\section{Santrauka}

Branduolinių elektrinių eksploatacijos metu medžiagų senejjimo procesai, tokie kaip korozija, nuovargis, valkšnumas ir kiti, daro didelę ittaką komponentų vientisumui. Vienas iš senejjimo procesų - tai vandenilio absorbcija. Kai vandenilio koncentracija cirkonio lydinyje viršija jo tirpumo ribą, pradeda formuotis cirkonio hidridai, kurie lemia cirkonio medžiagos mechanines savybes. Todèl labai svarbu nustatyti cirkonio mechanines savybes esant skirtingoms vandenilio koncentracijoms. Iprastai jos nustatomos atliekant ekspe- rimentą, tačiau tai ne visada yra ịmanoma. Reikalingi alternatyvūs mechaninių savybių nustatymo metodai. Šiame straipsnyje pristatomas skaitinis cirkonio lydinio su hidridais mechaninių savybių prognozavimas. Jis atliktas naudojant baigtinių elementų metodą. Šiam tikslui sukurtas baigtinių elementų modelis, kuriame sumodeliuotas cirkonio lydinio hidridas, apsuptas cirkonio lydinio matricos. Hidrido dydis ir geometrija buvo eksperimentiškai matuoti realiame bandinyje. Cirkonio lydinys, supantis hidridą, baigtinių elementų modelyje parinktas taip, kad hidrido tūrinè dalis tenkintų eksperimentinius matavimus. Skaitinès prognozès rezultatai buvo palyginti su eksperimento duomenimis, nustatytas geras sutapimas.

Raktažodžiai: baigtinių elementų metodas, hidridas, vandenilis, cirkonio lydinys, mechaninès savybès 